\title{
The Impact of Domestic Public Debt on Financial Development in Malaysia
}

\author{
Mok Wei Mun \\ School of Graduates Studies, University Putra Malaysia \\ 43400 Serdang, Selangor, Malaysia \\ E-mail: weimun_88@hotmail.com

\begin{abstract}
Normaz Wana Ismail ${ }^{1}$
Institute of Agricultural and Food Policy, University Putra Malaysia

43400 Serdang, Selangor, Malaysia

and

Department of Economics

Faculty of Economics and Management, University Putra Malaysia

43400 Serdang, Selangor, Malaysia

E-mail: nwi@upm.edu.my
\end{abstract}

Received: February 26, 2015 Accepted: March 25, 2015 Published: April 16, 2015

doi:10.5296/ijssr.v3i2.7167 URL: http://dx.doi.org/10.5296/ijssr.v3i2.7167

\begin{abstract}
When the government heavily borrows domestically from the banking sector to finance its expenditures, there is possibility that public debt will lead to a crowding out effect on private investment since bank credit is a primary funding source for the private sector. This study examines the linkages between domestic public debt and financial development in Malaysia for the period of 1980 to 2010. Our analysis suggests that domestic public debt from banks has a negative relationship with financial development. Meanwhile, the crowding out effect is

\footnotetext{
${ }^{1}$ Corresponding author: Institute of Agricultural and Food Policy, University Putra Malaysia, 43400 Serdang, Selangor, Malaysia Tel.: 603-89471067. E-mail: nwi@upm.edu.my. Any remaining errors or omissions rest solely with the authors of this paper.
} 
evident during the occurrence of financial crises.

Keywords: Domestic Public Debt, Financial Development, Crowding Out, Autoregressive Distributed Lag (ARDL)

JEL Classifications: G21, H62, H63

\section{Introduction}

It is widely believed that the government spending plays an important role to influence the level of economic growth. However, a large size of government spending can lead to a budget deficit when expenses exceed tax revenues. In general, the government can always impose taxes, borrow from domestic and foreign sources, or print money to reduce the size of the budget deficit (Feldstein, 1985; Adam \& Bevan, 2005; Loganathan, Sukemi, \& Sanusi, 2010). As a result, the budget deficit is always associated with a large debt burden when borrowing is a financing option.

In today's fast-changing and competitive world, the development of the financial system is a crucial factor in the process of economic development (Kablan, 2010). As we know, Malaysia aims to transform from a middle-income country to a high value-added and high-income country by 2020. For that reason, the country requires a strong financial system to withstand the global challenges. Meanwhile, the government has incurred large public debt in order to meet its high development expenditure. For example, the size of total public debt (domestic and foreign) has accelerated at an alarming rate and reached RM 617,463 million ${ }^{2}$ or 53.6 per cent of GDP in 2010.

Given the high liquidity in the banking system, the government can continue to borrow and rely on domestic sources to reduce the gap of deficit. However, higher domestic debt may cause a crowding out effect and affect the financial stability if banks become extremely involved in government debt (Panizza, 2008). When banks hold their large proportional assets in government debt, it will reduce the amount of bank credit available to private sector and restrict private investment (Emran \& Farazi, 2009). Since bank credit is a primary funding source for the private sector, the implication of public debt leading to a crowding out effect on private investment has become an important issue among both fiscal policy makers and the banking sector.

The negative impact of public debt on financial development through the crowding out effect is empirically ambiguous. According to Hauner (2009), the role of public debt in financial development can be discussed from the "safe asset" view and the "lazy bank" view. Public debt serves as collateral for depositors and provides a benchmark for the private sector in supporting the financial development (Kumhof \& Tanner, 2005). However, the increase in public debt held by the banking sector might be critical for the financial development, as higher interest rates limit the availability of bank credit to private sectors (Ismihan \& Ozkan, 2012).

\footnotetext{
2 Source: Ministry of Finance, Bank Negara Malaysia
} 
In summary, this study is different from Hauner $(2008,2009)$ and Ismihan and Ozkan (2012) when analysing the crowding out effect from the banking perspective. Existing studies on the crowding out hypothesis did not consider the country specific level, especially Malaysia. Thus, there is still a gap since the crowding out effects on financial development has yet to be empirically examined. Beginning 2009, the banking sector has substituted its role as a social security institution to become the largest domestic debt holder in Malaysia (See appendix). Nevertheless, higher borrowing from domestic sources may not crowd out private investment as long as the activity requirement can be met by higher saving rate. ${ }^{3}$ Although the trend of domestic debt has been increasing for years, yet the empirical evidence of a relationship between domestic public debt and financial development is limited in existing studies. Therefore, the objective of this study is to examine the impact of public debt, particularly focusing on the role of domestic public debt from the banking system on financial development in Malaysia.

The organization in this study can be divided as follows: section two highlights relevant literatures; section three presents the data and methodology; section four reports the results and the last section summarizes our conclusion and recommendation.

\section{Literature Review}

According to Buiter and Patal (1992), one of the concerns that governments have on the accumulation of public debt is the crowding out effect. This effect can be demonstrated through the IS-LM macroeconomic model where an increase in government spending shifts the IS curve to the right. Meanwhile, the upward sloping IS curve further reduces private borrowing and crowds out private investment (Spector \& Cott, 1988; Munduch, 1991; Vamvoukas, 1999).

There are also debates on the crowding in and crowding out affects based on different economic school of thoughts. The Keynesian theory suggests that government expenditures increases aggregate demand through the multiplier effect, such as when the government injects money to encourage consumption and leads to higher demand in private consumption. Therefore, firms who want to make more profit should increase private investment to induce the crowding in effect (Baldacci, Hillman, \& Kojo, 2004; Cwik \& Wieland, 2011). On the other hand, the Neoclassical theory disagrees and criticizes that outstanding government spending causes higher interest rate and leads to a reduction in private investment due to the higher cost of borrowing (Aschauner, 1989; Bernheim, 1989; Wang, 2005).

Empirical support on the crowding in versus crowding out issues remains ambiguous. Caballero and Krishnamurthy (2004) pointed out that crowding out effect is significantly evident in emerging countries due to the lower financial depth in response to Keynesian fiscal policies. Cottarelli, Dell'Ariccia, and Vladkova-Hollar, (2005) found that the negative elasticity of public debt supports a crowding out effect on the private sector credit in Central and Eastern Europe, and the Balkans (CEB) countries. In contrast, Bahmani-Oskooee (1999) argued that fiscal deficit has a positive effect on private investment, supporting the crowding

\footnotetext{
3 Source: Economic Report 2007/2008, Ministry of Finance Malaysia
} 
in effect. Alani and Emad (2006) also did not find evidence of a crowding out in the Japanese economy where the increasing use of government bonds to finance the country's deficit is not sensitive to domestic interest rate. Meanwhile, the mixed crowding in and crowding out effects can occur concurrently based on the components of government expenditure. For example, a productive government spending increases the performance of private investment while unproductive spending discourages private investment (Ahmed \& Miller, 2000).

The crowding in or crowding out effects can be presented through several channels. First, the crowding out effect can be seen from the impact of public investment on private investment (Argimon, Gonzalez-Paramo, \& Roldan, 1997; Erden \& Holcombe, 2006; Hatano, 2010; Furceri \& Sousa, 2011). Alternatively, the evidence of crowding in or crowding effects can be established through the linkages between budget deficit and interest rate (Burney, Yasmeen, \& Niazi, 1989; Darrat, 2002; Cebula, 2003).

However, these studies have overlooked the effect of crowding out through the financial channel. There is little evidence on the crowding out effect of public debt on financial development. Majumder (2007) stated that the crowding out effect of government borrowing on private credit is not necessarily detrimental to private investment if the country has high liquidity in the financial system. Meanwhile, Hauner (2008) summarized that a large proportion of public debt absorbed by banks can increase the profitability but constraint the efficiency of the banking sector. Once again, the role of public debt in financial development was investigated by Hauner (2009), where both banking-level and country-level analysis showed that public sector credit has a negative effect on financial development. This result is in line with the "lazy banks" view, which suggests that banks earn profit when making loans to the government but reduce the efficiency in the banking sector. Recently, Ismihan and Ozkan (2012) have concluded the existence of crowding out effect based on a large scale banking level and country level.

\section{Data and Methodology}

The annual time series data in this study cover from 1980 to 2010. All data are collected from various sources such as the Ministry of Finance, the Central Bank of Malaysia, the World Bank and the International Monetary Funds. Meanwhile, the components for domestic public debt consist of the Malaysian Government Securities (MGS), the Malaysian Treasury Bills (MTB) and the Government Investment Issues (GII). Appendix A presents the descriptive statistics analysis and figure for public debt in Malaysia which showed that the amount of domestic public debt had increased gradually and was accounted at RM 390,356 million or 63.2 percent of total public debt in 2010 .

For cointegration analysis, this study employs the Autoregressive Distributed Lag (ARDL) technique proposed by Pesaran, Shin, and Smith (2001) to examine the long run and short run relationships among the variables. The ARDL cointegration bounds test is a popular method used by researchers because it has several advantages compared to other cointegration techniques. Firstly, ARDL method does not require any pre-testing on variables, which the order of integration underlying the regressors can be purely stationary $\mathrm{I}(0)$, purely non stationary I(1) or combination of both properties. Secondly, the ARDL model is applicable for 
short-time sample period. Thirdly, ARDL method provides a robust result in both long run and short run relationships simultaneously without losing any long run information.

Since the macroeconomic variables are non-stationary and may reflect spurious regression, a unit root test is implemented prior to the ARDL cointegration analysis. Although the ARDL method allows exemption from pre-tests on variables, the unit root test is essential to ascertain that the dependent variable does not exceed I(1). In this study, the Augmented Dickey-Fuller (ADF) test and Phillips-Perron (PP) test are conducted to determine the order of integration underlying the ARDL model.

In order to measure the cointegration relationship between domestic public debt and financial development, this study adopts the following model where all variables are in logarithmic forms.

$$
L F D_{\mathrm{t}}=\alpha+\beta_{1} L D D_{\mathrm{t}}+\beta_{2} L I N F_{\mathrm{t}}+\beta_{3} L D I R_{\mathrm{t}}+\beta_{4} L R G D P_{\mathrm{t}}+\mu_{\mathrm{t}}
$$

LFD is a proxy for financial development by the log of bank credit to the private sector. Specifically, this paper followed Ismihan and Ozkan (2012), in which bank credit to private sector was used as a proxy because it has excluded the credit availability of public sector. The main hypothesized variable employed in this model is log of domestic public debt from the banking system in terms of GDP, which is denoted as LDD. Other control variables namely inflation rate (LINF), deposit interest rate (LDIR) and real GDP (LRGDP) are included in this model. These variables have been used as a determinant of financial development by previous researchers, such as Cottarelli et al. (2005), Guo and Stepanyan (2011), and Tan (2012).

Bank credit to the private sector can be defined as the volume of financial resources provided by banks to the private sector to finance their private investment. The larger debt, that the government borrows from banks to finance its fiscal deficit, the smaller the bank credit available to be absorbed by the private sector. Besides, there is the risk of rising inflation rates that may lower the rate of return on investment. As a result, inflation rate is expected to have a negative relationship with private credit which eventually affected the financial development. At the same time, the size of total deposit in banks expands consistently with a higher deposit interest rate. A higher deposit rate benefits the depositors but poses a disadvantage to borrowers. Since this study is from the standpoint of the banks, an increase in the deposit interest rate is expected to increase the size of funds. Bank lending to the private sector expands and positively crowds in private investment and financial development. Lastly, real GDP takes into account the development of market size. The scope of credit available for private investment increases with market size, followed by economic growth. Here, private credit is expected to have a positive relationship with real GDP.

The ARDL bound test has been employed based on the Unrestricted Error Correction Model (UECM). For robustness analysis, Equation (1) is divided into three separate models as follows:

Model A: $\Delta \mathrm{L} F D_{\mathrm{t}}=\alpha+\lambda_{1} \mathrm{~L} F D_{\mathrm{t}-1}+\lambda_{2} \mathrm{~L} D D_{\mathrm{t}-1}+\lambda_{3} \mathrm{~L} I N F_{\mathrm{t}-1}+\lambda_{4} \mathrm{~L} D I R_{\mathrm{t}-1}+\lambda_{5} \mathrm{~L} R G D P_{\mathrm{t}-1}$ 


$$
\begin{aligned}
& +\sum_{i=1}^{m} \beta_{1 \mathrm{i}} \Delta \mathrm{L} F D_{-\mathrm{i}}+\sum_{i=0}^{n} \beta_{2 \mathrm{i}} \Delta \mathrm{L} D D_{\mathrm{t}-\mathrm{i}}+\sum_{i=0}^{p} \beta_{3 \mathrm{i}} \Delta \mathrm{L} I N F_{\mathrm{t}-\mathrm{i}} \\
& +\sum_{i=0}^{q} \beta_{4 \mathrm{i}} \Delta \mathrm{L} D I R_{\mathrm{t}-\mathrm{i}}+\sum_{i=0}^{r} \beta_{5 \mathrm{i}} \Delta \mathrm{L} R G D P_{\mathrm{t}-\mathrm{i}}+\mathrm{e}_{\mathrm{t}}
\end{aligned}
$$

Model B: $\Delta \mathrm{L} F D_{\mathrm{t}}=\alpha+\lambda_{1} \mathrm{~L} F D_{\mathrm{t}-1}+\lambda_{2} \mathrm{~L} D D_{\mathrm{t}-1}+\lambda_{3} \mathrm{~L} I N F_{\mathrm{t}-1}+\lambda_{4} \mathrm{~L} D I R_{\mathrm{t}-1}+\lambda_{5} \mathrm{~L} R G D P_{\mathrm{t}-1}$

$$
\begin{aligned}
& +\sum_{\mathrm{i}=1}^{\mathrm{m}} \beta_{1 \mathrm{i}} \Delta \mathrm{L} F D_{\mathrm{t}-\mathrm{i}}+\sum_{\mathrm{i}=0}^{\mathrm{n}} \beta_{2 \mathrm{i}} \Delta \mathrm{L} D D_{\mathrm{t}-\mathrm{i}}+\sum_{\mathrm{i}=0}^{\mathrm{p}} \beta_{3 \mathrm{i}} \Delta \mathrm{L} I N F_{\mathrm{t}-\mathrm{i}} \\
& +\sum_{\mathrm{i}=0}^{\mathrm{q}} \beta_{4 \mathrm{i}} \Delta \mathrm{L} D I R_{\mathrm{t}-\mathrm{i}}+\sum_{\mathrm{i}=0}^{\mathrm{r}} \beta_{5 \mathrm{i}} \Delta \mathrm{L} R G D P_{\mathrm{t}-\mathrm{i}}+\delta_{1} \mathrm{DUM}_{\mathrm{t}}+\mathrm{e}_{\mathrm{t}}
\end{aligned}
$$

Model C: $\Delta \mathrm{L} F D_{\mathrm{t}}=\alpha+\lambda_{1} \mathrm{~L} F D_{\mathrm{t}-1}+\lambda_{2} \mathrm{~L} D D_{\mathrm{t}-1}+\lambda_{3} \mathrm{~L} I N F_{\mathrm{t}-1}+\lambda_{4} \mathrm{~L} D I R_{\mathrm{t}-1}+\lambda_{5} \mathrm{~L} R G D P_{\mathrm{t}-1}$

$$
\begin{aligned}
& +\sum_{\mathrm{i}=1}^{\mathrm{m}} \beta_{1 \mathrm{i}} \Delta \mathrm{L} F D_{\mathrm{t}-\mathrm{i}}+\sum_{\mathrm{i}=0}^{\mathrm{n}} \beta_{2 \mathrm{i}} \Delta \mathrm{L} D D_{\mathrm{t}-\mathrm{i}}+\sum_{\mathrm{i}=0}^{\mathrm{p}} \beta_{3 \mathrm{i}} \Delta \mathrm{L} I N F_{\mathrm{t}-\mathrm{i}} \\
& +\sum_{\mathrm{i}=0}^{\mathrm{q}} \beta_{4 \mathrm{i}} \Delta \mathrm{L} D I R_{\mathrm{t}-\mathrm{i}}+\sum_{\mathrm{i}=0}^{\mathrm{r}} \beta_{5 \mathrm{i}} \Delta \mathrm{L} R G D P_{\mathrm{t}-\mathrm{i}}+\gamma_{1}\left(\mathrm{DUM}^{*} \mathrm{~L} D D\right)_{\mathrm{t}}+\mathrm{e}_{\mathrm{t}}
\end{aligned}
$$

where $\Delta$ is the first difference operator, $\alpha$ is the drift component, $m, n, p, q$ and $r$ are the optimal lag lengths in the ARDL model and $e_{t}$ is the white noise error term. $\lambda_{1}$ to $\lambda_{5}$ represent the long run relationships in the model while $\beta 1 \mathrm{i}$ to $\beta 5 \mathrm{i}$ represent the short run dynamic relationships.

Model A investigates the impact of government domestic debt from bank on financial development. Since the Malaysian economy was badly affected during the 1997 financial crisis and 2008 European sovereign debt crisis, we introduce a dummy variable in Model B to capture the presence of a crisis due to an unanticipated shock. In this study, the values 0 represent the absence of crisis, while the values 1 indicate the occurrence of crisis for year 1997-1998 and 2008-2009. Unlike previous studies, this paper also aims to highlight the significant impact of domestic debt during a financial crisis on financial development. Therefore, an interaction term is added in Model $\mathrm{C}$ to examine the multiplier effect between financial crisis and domestic debt. In regression analysis, the response of variable to the crisis may yield a different result regarding the coefficient of the interaction term.

\section{Results}

Results from the unit root tests are reported in Table 1 and Table 2. We conclude from both 
tests that all variables except inflation rate, with constant and trend, are non-stationary at level. At first difference, all variables are found to be stationary of order one, or I(1), with constant and trend. Thus, we can reject the null hypothesis and conclude that unit root does not exist and all variables are statistically significant at 1 per cent, 5 per cent, and 10 per cent levels. Since there is a mix of I(0) and I(1) among the variables, ARDL bounds test is suitable to be applied in this study. Afterward, we can proceed to employ the cointegration analysis to examine the existence of a long run relationship between financial development and its determinants.

Table 1. Results from Augmented Dickey-Fuller Unit Root Test

\begin{tabular}{|c|c|c|c|c|}
\hline \multirow{2}{*}{ Variables } & \multicolumn{2}{|c|}{ Level } & \multicolumn{2}{|c|}{ First Difference } \\
\hline & Without Trend & With Trend & Without Trend & With Trend \\
\hline \multirow[t]{2}{*}{$\mathrm{LFD}$} & -1.990 & -2.033 & $-4.894 * * *$ & $-4.572 * * *$ \\
\hline & (3) & (3) & $(0)$ & (1) \\
\hline \multirow[t]{2}{*}{$\mathrm{L} D D$} & -1.046 & 0.194 & $-3.997 * * *$ & $-4.202 * *$ \\
\hline & (3) & $(0)$ & $(0)$ & $(0)$ \\
\hline \multirow[t]{2}{*}{ LINF } & $-3.352 * *$ & $-3.296^{*}$ & $-7.979 * * *$ & $-7.838 * * *$ \\
\hline & (3) & (3) & $(0)$ & $(0)$ \\
\hline \multirow[t]{2}{*}{$\mathrm{L} D I R$} & -1.340 & -3.201 & $-3.680 * *$ & $-3.569 *$ \\
\hline & $(0)$ & (1) & (3) & (3) \\
\hline \multirow[t]{2}{*}{ LRGDP } & -1.013 & -1.110 & $-4.336 * * *$ & $-4.335 * * *$ \\
\hline & $(0)$ & $(0)$ & (0) & $(0)$ \\
\hline
\end{tabular}

Note: The asterisks $* * *, * *$, and $*$ denote statistical significance at $1 \%, 5 \%$, and $10 \%$ level, respectively. The figure in parenthesis (...) represents the optimal lag length selected based on the Akaike Information Criterion (AIC).

Table 2. Results from Phillip-Perron Unit Root Test

\begin{tabular}{|c|c|c|c|c|}
\hline \multirow{2}{*}{ Variables } & \multicolumn{2}{|c|}{ Level } & \multicolumn{2}{|c|}{ First Difference } \\
\hline & Without Trend & With Trend & Without Trend & With Trend \\
\hline \multirow[t]{2}{*}{ LFD } & -2.607 & -2.007 & $-4.883 * * *$ & $-5.089 * * *$ \\
\hline & (3) & (3) & (3) & (2) \\
\hline \multirow[t]{2}{*}{$\mathrm{L} D D$} & -0.278 & -0.202 & $-4.046^{* * *}$ & $-4.159 * *$ \\
\hline & (3) & (3) & (3) & (2) \\
\hline \multirow[t]{2}{*}{$\mathrm{LINF}$} & $-3.207 * *$ & $-3.248 *$ & $-7.881 * * *$ & $-7.750 * * *$ \\
\hline & (1) & (0) & (1) & (1) \\
\hline \multirow[t]{2}{*}{$\mathrm{LDIR}$} & -1.182 & -2.781 & $-7.892 * * *$ & $-7.394 * * *$ \\
\hline & (5) & (4) & (23) & (24) \\
\hline \multirow[t]{2}{*}{$\mathrm{L} R G D P$} & -0.974 & -1.330 & $-4.347 * * *$ & $-4.346^{* * *}$ \\
\hline & (2) & (2) & (1) & (1) \\
\hline
\end{tabular}

Note: The asterisks $* * *, * *$, and $*$ denote statistical significance at $1 \%, 5 \%$, and $10 \%$ level, respectively. The figure in parenthesis (...) represents the bandwidth used in the KPSS test selected based on the Newey-West Bandwidth criterion. 


\section{ARDL Bounds Test for Cointegration Analysis}

Table 3. F-statistics for Long Run Cointegration

\begin{tabular}{|c|c|c|}
\hline Model & \multicolumn{2}{|c|}{ F-Statistic } \\
\hline Model A: LFD=f(LDD,LINF,LDIR,LRGDP) & \multicolumn{2}{|c|}{$8.259 * * *$} \\
\hline Model B: LFD $=f(\mathrm{~L} D D, \mathrm{LINF}, \mathrm{L} D I R, \mathrm{~L} R G D P, D U M)$ & \multicolumn{2}{|c|}{$6.899 * * *$} \\
\hline \multirow[t]{2}{*}{ Model C: LFD $=f(\mathrm{~L} D D, \mathrm{LINF}, \mathrm{L} D I R, \mathrm{~L} R G D P, D U M * D D)$} & \multicolumn{2}{|c|}{$7.362 * * *$} \\
\hline & \multicolumn{2}{|c|}{$\mathrm{k}=4, \mathrm{n}=31$} \\
\hline Narayan (2005) Critical Value & $\begin{array}{c}\text { Lower Bound } \\
\qquad I(0)\end{array}$ & $\begin{array}{c}\text { Upper Bound } \\
I(1)\end{array}$ \\
\hline $1 \%$ & 4.768 & 6.670 \\
\hline $5 \%$ & 3.354 & 4.774 \\
\hline $10 \%$ & 2.752 & 3.994 \\
\hline
\end{tabular}

Note: Critical values are obtained from Narayan (2005) (Table Case III: Unrestricted intercept and no trend; pg. 1988). The asterisks $* * *, * *$, and $*$ denote statistical significance at $1 \%, 5 \%$, and $10 \%$ level, respectively.

There are two steps in the ARDL cointegration bounds testing. At the beginning, OLS is applied to determine the existence of a long run relationship between financial development and its determinants: domestic public debt, inflation rate, deposit interest rate and real GDP. First, we calculate F-statistics and compare the results with the critical value tabulated in Table Case III from Narayan (2005). The computed F-statistic for model A of 8.259 is greater than the upper bound critical value of 6.670 at 1 per cent significance level. Thus, we can reject the null hypothesis and conclude that there is a strong long run relationship between the variables. When a dummy variable that represents the period of financial crisis is introduced in Model B, the F-statistic is slightly smaller at 6.899 and the null hypothesis can be rejected at 1 per cent significance level. Then, we add the interaction form variable to Model $\mathrm{C}$ where the statistics also indicate the existence of a long run relationship between the variables at 1 per cent significance level.

The results in Table 4 summarize ARDL estimates for the three models. We estimate the coefficient for the long run relationship in the second step only when we have supportive evidence from the F-statistics. Narayan (2005) suggested that the lag selection based on the Schwarz Bayesian Criterion (SBC), which is known as a parsimonious specification, is more suitable than the Akaike Information Criterion (AIC). Since the sample size of annual time series data used in this study is very small, we can use SBC and the maximum of two lags to estimate the long run elasticity of each variable. 
Table 4. ARDL Estimates of Long Run Coefficients

\begin{tabular}{lccc}
\hline Variable & Model A & Model B & Model C \\
& $(1,0,0,0,0)$ & $(1,1,2,0,0)$ & $(1,1,2,0,0)$ \\
\hline LDD & -0.164 & $-0.277^{* *}$ & $-0.351^{* * *}$ \\
& $(0.098)$ & $(0.143)$ & $(0.103)$ \\
LINF & $-0.199^{* *}$ & -0.114 & $-0.177^{* *}$ \\
& $(0.090)$ & $(0.080)$ & $(0.078)$ \\
LDIR & $0.603^{* *}$ & 0.221 & $0.386^{* *}$ \\
& $(0.278)$ & $(0.182)$ & $(0.162)$ \\
LRGDP & $0.619^{* * *}$ & $0.411^{* * *}$ & $0.483^{* *}$ \\
& $(0.170)$ & $(0.127)$ & $(0.114)$ \\
INPT & -4.220 & -1.421 & -2.705 \\
& $(2.319)$ & $(1.713)$ & $(1.510)$ \\
DUM & & $0.290^{* *}$ & \\
& & $(0.117)$ & $2.448^{* *}$ \\
DUM ${ }^{*}$ LDD & & & $(0.882)$ \\
\end{tabular}

Note: The dependent variable is LFD and the lag length is selected based on the Schwarz Bayesian Criterion (SBC). The asterisks ***,**, and * denote statistical significance at $1 \%, 5 \%$, and $10 \%$ level, respectively. The figure in parenthesis $(\ldots)$ represents the standard error in the estimation of ARDL framework.

In regression model, INPT is known as intercept which included in the model to explain the value of dependent variable $(\mathrm{Y})$ when all the predictors variables $(\mathrm{X})$ are equal to zero. In the long run, all independent variables show the expected signs which are consistent with the earlier hypothesis. The domestic debt variable, $L D D$, is used to examine the impact of domestic debt on financial development. The coefficient of LDD in Model A shows a negative sign but is statistically insignificant. This finding corresponds with Majumder (2007), who suggested that bank lending does not provide evidence of a crowding out effect on financial development. However, when the dummy variable for financial crisis is included in Model B, the estimate for $\mathrm{LDD}$ shows a different result with a negative elasticity of -0.277 , which is statistically significant at 5 per cent level. We conclude that external shocks have an indirect influence on the domestic debt and crowds out private spending.

To check for robustness, an interaction term between domestic debt and financial crisis is introduced in Model C, where the coefficient for $L D D$ is -0.351 and statistically significant at 1 per cent level. In this study, both negative signs for LDD in Model B and Model C are consistent with Ismihan and Ozkan (2012), where large government borrowing generates crowding out effect on the private sector and impedes financial development.

The positive sign for the coefficient of dummy variable (DUM) shown in Table 4 is 0.29 , which indicated that there is a positive relationship between financial crisis and financial development. In order to strengthen the financial system and recover from the 1997 financial turmoil, the former Prime Minister of Malaysia, Dr. Mahathir has implemented fixed exchange rate regime and capital control (Sufian, 2010). Furthermore, Malaysia's financial 
system, has undergone significant transformations, had become stronger and is able to stand firm against the financial crisis. Thus, this study revealed that there is a positive correlation between financial crisis and financial development during the period 1997-1998 and 2008-2009.

Next, the coefficient for the interaction term (DUM*LDD) shows a positive sign and is significant at 5 per cent level. This estimate implies that domestic debt has a positive impact on financial development during the period of crisis. Therefore, the government should avoid external debt and rely more on domestic debt. Not only minimizing the risk of external indebtedness, domestic debt also supports financial development in time of crisis.

Meanwhile, the negative coefficients for inflation rate (LINF) in Model A and Model C are consistent with the hypothesis, implying that financial development is adversely affected by higher inflation rate (Sharma \& Gounder, 2012). Although the estimate for LINF in Model B also show the expected negative sign, it is not statistically significant. The mixed results weakly support that inflation rate is a factor to influence the financial development when a financial crisis occurs.

In line with Ismihan and Ozkan (2012), the coefficients of deposit interest rate (LDIR) in Model A and Model $\mathrm{C}$ report a positive and significant finding. A higher deposit interest rate attracts more investors and expands the total deposit and financial depth. Through the banking sector, higher deposit interest rate increases bank lending availability and foster financial development. However, our finding in Model B indicates that deposit interest rate is statistically insignificant.

The coefficient for real GDP (LRGDP) has a positive sign and is statistically significant, which is consistent with our initial prediction. The estimates in all three models show that higher real GDP in Malaysia increases the demand for bank credit to private sector and promotes financial development. This finding is in agreement with Guo and Stepanyan (2011), who believed that a strong economic growth is one of the contributors to financial development.

Table 5 summarizes the empirical result for the dynamic short run coefficients. The computed lagged error correction coefficients (ECM) for all three models are highly significant at 1 per cent significance level. The respective values are $-0.42,-0.62$ and -0.67 , where the negative signs show the speed of adjustment for the disequilibrium due to short run shocks to achieve long run equilibrium. Our finding suggests that the speed of convergence of financial development in each model is 42 per cent, 62 per cent and 67 per cent, respectively. 
Table 5. Error Correction Representation for the ARDL Model

\begin{tabular}{lccc}
\hline Variable & Model A & Model B & Model C \\
& $(1,0,0,0,0)$ & $(1,1,2,0,0)$ & $(1,1,2,0,0)$ \\
\hline $\mathrm{dLDD}$ & -0.070 & $-0.449^{* *}$ & $-0.469^{* * *}$ \\
& $(0.733)$ & $(0.175)$ & $(0.154)$ \\
$\mathrm{dLINF}$ & $-0.843^{* *}$ & $-0.091^{* *}$ & $-0.092^{* * *}$ \\
& $(0.037)$ & $(0.034)$ & $(0.031)$ \\
$\mathrm{dLINF1}$ & & $-0.063^{* *}$ & $-0.635^{* *}$ \\
& & $(0.026)$ & $(0.024)$ \\
$\mathrm{dLDIR}$ & $0.256^{* * *}$ & 0.136 & $0.220^{* *}$ \\
& $(0.082)$ & $(0.105)$ & $(0.086)$ \\
$\mathrm{dLRGDP}$ & $0.262^{* * *}$ & $0.253^{* *}$ & $0.276^{* * *}$ \\
& $(0.083)$ & $(0.091)$ & $(0.084)$ \\
$\mathrm{dINPT}$ & -1.789 & -0.875 & -1.546 \\
& $(0.871)$ & $(1.038)$ & $(0.872)$ \\
$\mathrm{d} D U M$ & & $0.179^{* *}$ & \\
dDUM*LDD & $(0.080)$ & $1.399^{* * *}$ \\
& & & $(0.488)$ \\
ecm(-1) & & & $-0.572^{* * *}$ \\
& $-0.424^{* * *}$ & $-0.616^{* * *}$ & $(0.133)$ \\
\hline
\end{tabular}

Note: The dependent variable is LFD and the lag length is selected based on the Schwarz Bayesian Criterion (SBC). The asterisks ***, **, and $*$ denote statistical significance at $1 \%, 5 \%$, and $10 \%$ level, respectively. The figure in parenthesis (...) represents the standard error in the estimation of ARDL framework.

Table 6. Results from Autoregressive Distributed Lag (ARDL) Diagnostic Test

\begin{tabular}{lccc}
\hline Diagnostic Test & Model A & Model B & Model C \\
\hline Serial Correlation & $\mathbf{1 . 8 9 2}$ & 3.091 & $\mathbf{2 . 1 7 3}$ \\
& {$[0.813]$} & {$[0.097]$} & {$[0.159]$} \\
Functional Form & 0.577 & $\mathbf{0 . 9 0 1}$ & $\mathbf{0 . 1 4 9}$ \\
& {$[0.456]$} & {$[0.356]$} & {$[0.704]$} \\
Heteroscedasticity & 2.289 & $\mathbf{1 . 1 1 6}$ & $\mathbf{1 . 0 5 0}$ \\
& {$[0.142]$} & {$[\mathbf{0 . 3 0 1 ]}$} & {$[0.315]$} \\
\hline
\end{tabular}

Note: The figure in parenthesis $[\ldots]$ represents the $p$-value.

Table 6 presents the robustness test results for diagnostic checking. The probability values in all three models are greater than 0.05 , which strongly suggest that the models are free from serial correlation and heteroscedasticity problems. The diagnostic results also imply that the models are in their correct functional forms and have no specification error.

Finally, the Cumulative Sum of Recursive Residuals (CUSUM) test and Cumulative Sum of Squares of Recursive Residuals (CUSUMSQ) test are conducted to test the stability of the linear regression model over time. The figures clearly show the plots in which both the 
CUSUM test and CUSUMSQ test statistics do not exceed the 5 per cent significance level boundaries. Hence, we can conclude that the equation parameters in all three models are stable over the sample period (Appendix).

\section{Conclusion}

The empirical results show that the domestic public debt from banks has a statistically negative impact on the financial development during the period of financial crisis. In summary, an expansionary fiscal policy is likely to impair the economic growth when government expenditure exceeds tax revenue. According to the Neoclassical theory, an expansionary fiscal policy tends to increase the real interest rate and reduce the amount of borrowing in the private sector. Since bank credit to the private sector is related to private investment, the evidence of crowding out effect through financial development found in this study is consistent with Neoclassical view.

The stability and competitiveness of the financial system is vital to support the Malaysian transformation towards becoming a high value-added and high-income country. Unfortunately, debt financed budget deficit might affect the financial development through the crowding out effect. Following the 1997 Asian financial crisis, the government has relied on domestic debt to finance its economic development activities. Although domestic debt is less risky than external debt, the country's economy might face a crowding out effect and debt overhang, particularly if the amount of domestic public debt increases dramatically. Consequently, the government is urged to consider reducing domestic debt to a manageable level to enhance economic growth.

This study focuses on domestic public debt due to the limited availability of data on external public debt. The data on public debt used in this study also does not distinguish between domestic banks and foreign banks. Therefore, further analysis of public debt and financial development can focus on the public debt from strictly domestic banks for a more robustness finding.

\section{References}

Adam, C. S., \& Bevan, D. L. (2005). Fiscal deficits and growth in developing countries. $\begin{array}{llll}\text { Journal of Public } & \text { Economics, } & \text { 89(4), }\end{array}$ http://dx.doi.org/10.1016/j.jpubeco.2004.02.006

Ahmed, H., \& Miller, S. M. (2000). Crowding out and crowding in effects of the components of government expenditure. Contemporary Economic Policy, 18(1), 124-133. http://dx.doi.org/10.1111/j.1465-7287.2000.tb00011.x

Alani, A., \& Emad, M. A. (2006). Crowding out and crowding in effects of government bonds market on private sector investment (a Japanese case study). Institute of Developing Economies Discussion Paper, (74).

Argimon, I., Gonzalez-Paramo, J. M., \& Roldan, J. M. (1997). Evidence of public spending crowding out from a panel of OECD countries. Applied Economics, 29(8), 1001-1010. http://dx.doi.org/10.1080/000368497326390 
Aschauer, D. A. (1989). Does public capital crowd out private capital? Journal of Monetary Economics, 24(2), 171-188. http://dx.doi.org/10.1016/0304-3932(89)90002-0

Bahmani-Oskooee, M. (1999). Do federal budget deficits crowd out or crowd in private investment? Journal of Policy Modeling, 21(5), 633-640. http://dx.doi.org/10.1016/S0161-8938(98)00005-2

Baldacci, E., Hillman, A. L., \& Kojo, N. C. (2004). Growth, governance, and fiscal policy transmission channels in low-income countries. European Journal of Political Economy, 20(3), 517-549. http://dx.doi.org/10.1016/j.ejpoleco.2003.12.002

Bernheim, B. D. (1989). A neoclassical perspective on budget deficits. The Journal of Economic Perspectives, 3(2), 55-72. http://dx.doi.org/10.1257/jep.3.2.55

Buiter, W. H., \& Patel, U. R. (1992). Debt, deficits, and inflation: An application to the public finances of India. Journal of Public Economics, 47(2), 171-205. http://dx.doi.org/10.1016/0047-2727(92)90047-J

Burney, N. A., Yasmeen, A., \& Niazi, M. K. (1989). Government budget deficits and interest rates: An empirical analysis for Pakistan [with comments]. The Pakistan Development Review, 28(4), 971-980.

Caballero, R. J., \& Krishnamurthy, A. (2004). Fiscal policy and financial depth (No. w10532). National Bureau of Economic Research. http://dx.doi.org/10.3386/w10532.

Cebula, R. (2003). Budget deficits and real interest rates: Updated empirical evidence on causality. Atlantic Economic Journal, 31(3), 255-265. http://dx.doi.org/10.1007/BF02298819

Cottarelli, C., Dell'Ariccia, G., \& Vladkova-Hollar, I. (2005). Early birds, late risers, and sleeping beauties: Bank credit growth to the private sector in Central and Eastern Europe and in the Balkans. Journal of Banking and Finance, 29(1), 83-104. http://dx.doi.org/10.1016/j.jbankfin.2004.06.017

Cwik, T., \& Wieland, V. (2011). Keynesian government spending multipliers and spillovers in the euro area. Economic Policy, 26(67), 493-549. http://dx.doi.org/10.1111/j.1468-0327.2011.00268.x

Darrat, A. F. (2002). On budget deficits and interest rates: Another look at the evidence. International Economic Journal, 16(2), 19-29. http://dx.doi.org/10.1080/10168730200080010

Emran, M. S., \& Farazi, S. (2009). Lazy banks? Government borrowing and private credit in developing countries. Institute for International Economic Policy Paper Series, Working Paper, No. 29.

Erden, L., \& Holcombe, R. G. (2006). The linkage between public and private investment: A co-integration analysis of a panel of developing countries. Eastern Economic Journal, 32(3), 479-492.

Feldstein, M. (1985). Debt and taxes in the theory of public finance. Journal of Public Economics, 28(2), 233-245. http://dx.doi.org/10.1016/0047-2727(85)90071-4 
Furceri, D., \& Sousa, R. M. (2011). The impact of government spending on the private sector: Crowding out versus crowding in effects. Kyklos, 64(4), 516-533. http://dx.doi.org/10.1111/j.1467-6435.2011.00518.x

Geiger, L. T. (1990). Debt and economic development in Latin America. The Journal of Developing Areas, 24(2), 181-194.

Guo, K., \& Stepanyan, V. (2011). Determinants of bank credit in emerging market economies. IMF Working Papers, 1-20.

Hatano, T. (2010). Crowding in effect of public investment on private investment. Public Policy Review, 6(1), 105-110.

Hauner, D. (2008). Credit to government and banking sector performance. Journal of Banking and Finance, 32(8), 1499-1507. http://dx.doi.org/10.1016/j.jbankfin.2007.07.012

Hauner, D. (2009). Public debt and financial development. Journal of Development Economics, 88, 171-183. http://dx.doi.org/10.1016/j.jdeveco.2008.02.004

Ismihan, M., \& Ozkan, F. G. (2012). Public debt and financial development: A theoretical exploration. Economics Letter, 115, 348-351. http://dx.doi.org/10.1016/j.econlet.2011.12.040

Kablan, S. (2010). Banking efficiency and financial development in Sub-Saharan Africa. IMF Working Papers, WP/10/136. http://dx.doi.org/10.5089/9781455201198.001

Kumar, M., \& Woo, J. (2010). Public debt and growth. IMF Working Papers, 1-47. http://dx.doi.org/10.5089/9781455202188.001

Kumhof, M., \& Tanner, E. (2005). Government debt: A key role in financial intermediation (Vol. 5). International Monetary Fund.

Loganathan, N., Sukemi, M. N., \& Sanusi, N. A. (2010). External debt and macroeconomics performance in Malaysia: Sustainable or not? Global Economy and Finance Journal, 3(2), 122-132.

Majumder, A. (2007). Does public borrowing crowd out private investment? The Bangladesh evidence. Policy Analysis Unit, Working Paper Series, WP 708.

Misati, R. N., \& Nyamongo, E. M. (2011). Financial development and private investment in Sub-Saharan Africa. Journal of Economics and Business, 63(2), 139-151. http://dx.doi.org/10.1016/j.jeconbus.2010.10.001

Munduch, G. (1991). The importance of crowding out for the effectiveness of fiscal policy in Austria. Empirica, 18(1), 65-89. http://dx.doi.org/10.1007/BF00925002

Narayan, P. K. (2005). The saving and investment nexus for China: Evidence from

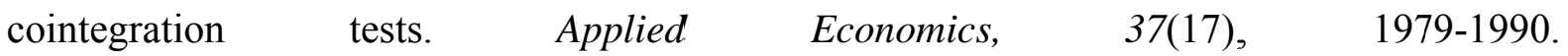
http://dx.doi.org/10.1080/00036840500278103

Panizza, U. (2008, March). Domestic and external public debt in developing countries. In United Nations Conference on Trade and Development Discussion Paper, No. 188. 
Pesaran, M. H., Shin, Y., \& Smith, R. (2001). Bound testing approaches to the analysis of level relationship. Journal of Applied Econometrics, 16, 289-326. http://dx.doi.org/10.1002/jae.616

Presbitero, A. F. (2012). Total public debt and growth in developing countries. European Journal of Development Research, 24(4), 606-626. http://dx.doi.org/10.1057/ejdr.2011.62

Reinhart, C. M., \& Rogoff, K. S. (2010). Growth in a time of debt. National Bureau of Economic Research. Working Papers, No. 15639. http://dx.doi.org/10.1257/aer.100.2.573

Sharma, P., \& Gounder, N. (2012). Determinants of bank credit in small open economies: The case of six Pacific Island Countries. Discussion Papers Finance, No 13. http://dx.doi.org/10.2139/ssrn.2187772

Saint-Paul, G. (1992). Fiscal policy in an endogenous growth model. The Quarterly Journal of Economics, 107(4), 1243-1259. http://dx.doi.org/10.2307/2118387

Spector, L. C., \& Cott, T. N. (1988). Crowding out, deficits, and interest rates: Comment. Public Choice, 58(1), 91-94. http://dx.doi.org/10.1007/BF00183332

Sufian, F. (2010). The impact of the Asian financial crisis on bank efficiency: The 1997 experience of Malaysia and Thailand. Journal of International Development, 22(7), 866-889. http://dx.doi.org/10.1002/jid.1589

Tan, T. B. (2012). Determinants of credit growth and interest margins in the Philippines and Asia. Asia and Pacific Department, IMF Working Paper, No.123. http://dx.doi.org/10.5089/9781475503524.001

Vamvoukas, G. A. (1999). Budget deficits and economic activity. International advances in economic research, 5(1), 65-73. http://dx.doi.org/10.1007/BF02295032

Wang, B. (2005). Effects of government expenditure on private investment: Canadian empirical evidence. Empirical Economics, 30(2), 493-504. http://dx.doi.org/10.1007/s00181-005-0245-9 


\section{Macrothink}

\section{Appendix}

\section{A.1 Descriptive Statistic}

\begin{tabular}{lccccc}
\hline & FD & DD & DIR & INF & RGDP \\
\hline Mean & 104.526 & 0.0934 & 5.454 & 3.131 & 286831.9 \\
Median & 107.696 & 0.083 & 4.890 & 3.039 & 282456.0 \\
Maximum & 158.505 & 0.237 & 9.750 & 9.700 & 559554.0 \\
Minimum & 49.011 & 0.055 & 2.080 & 0.290 & 100198.0 \\
Std. Dev. & 28.647 & 0.045 & 2.477 & 2.048 & 145789.6 \\
Skewness & -0.007 & 2.151 & 0.330 & 1.084 & 0.342 \\
Kurtosis & 2.435 & 7.359 & 1.649 & 4.682 & 1.839 \\
& & & & & \\
Jarque- Bera & 0.413 & 48.451 & 2.922 & 9.720 & 2.343 \\
Probability & 0.813 & 0.000 & 0.232 & 0.008 & 0.310 \\
& & & & & \\
Sum & 3240.303 & 2.906 & 169.080 & 97.048 & 8891789. \\
Sum Sq. Dev. & 24619.28 & 0.060 & 184.037 & 125.805 & $6.38 \mathrm{E}+11$ \\
& & & & & \\
Observation & 31 & 31 & 31 & 31 & 31 \\
\hline
\end{tabular}

\section{A.2 Domestic Public Debt in Malaysia in GDP}

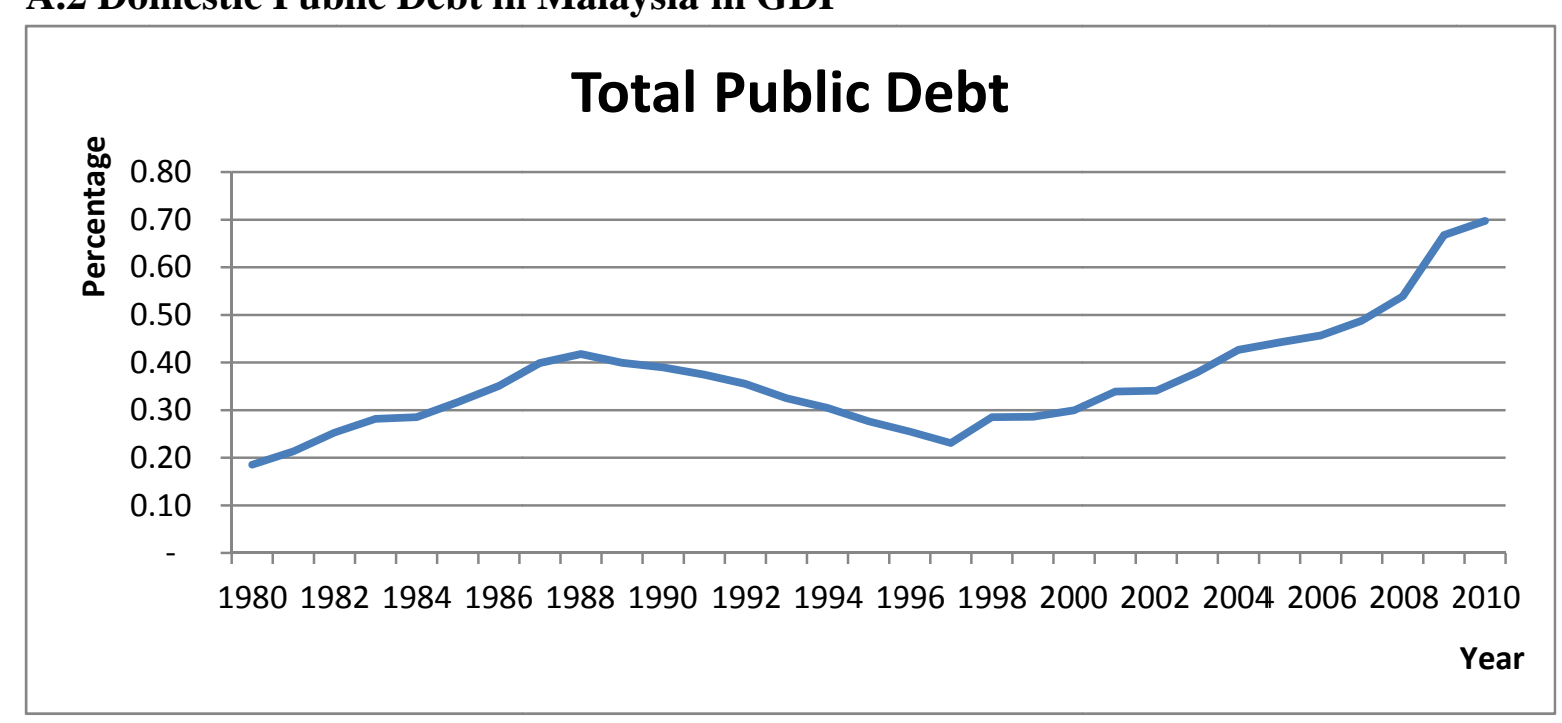

Source: Ministry of Finance, Central Bank of Malaysia 


\section{B.1 CUSUM and CUSUMSQ TEST (Model A)}

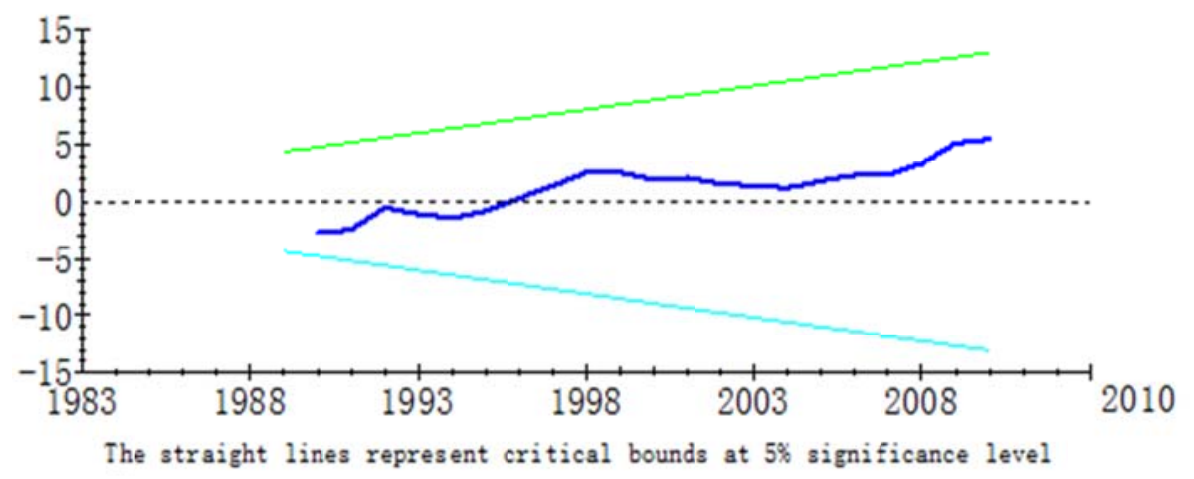

Figure 1. Cumulative sum of recursive residuals

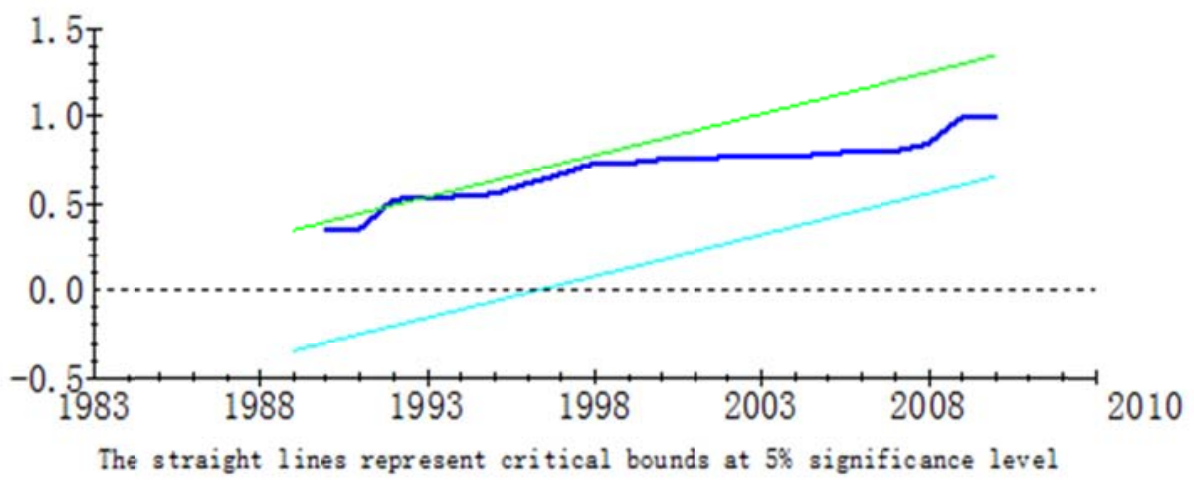

Figure 2. Cumulative sum of squares of recursive residuals

\section{B.2 CUSUM and CUSUMSQ TEST (Model B)}

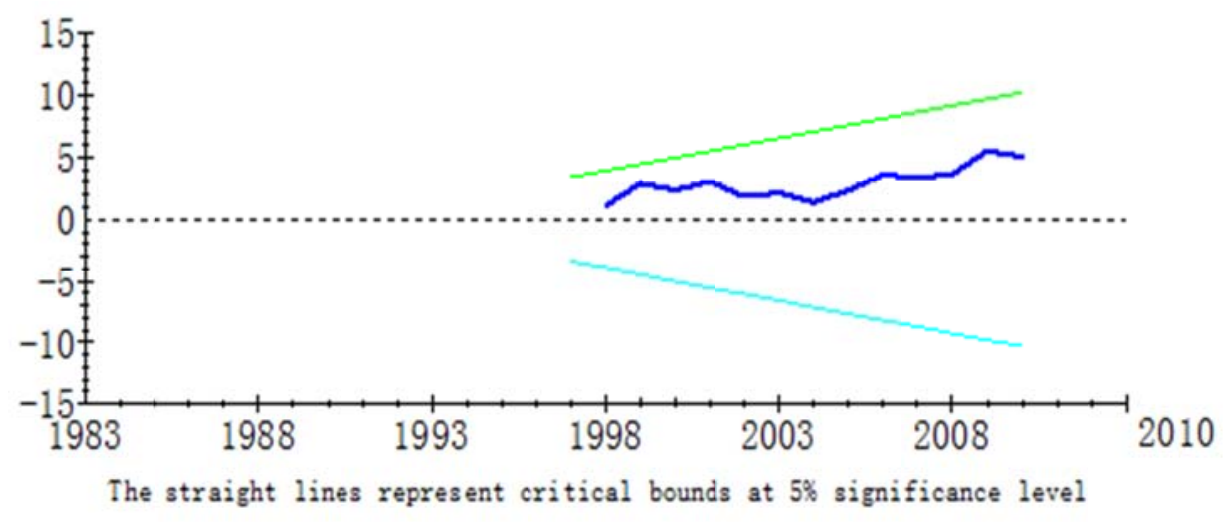

Figure 3. Cumulative sum of recursive residuals 


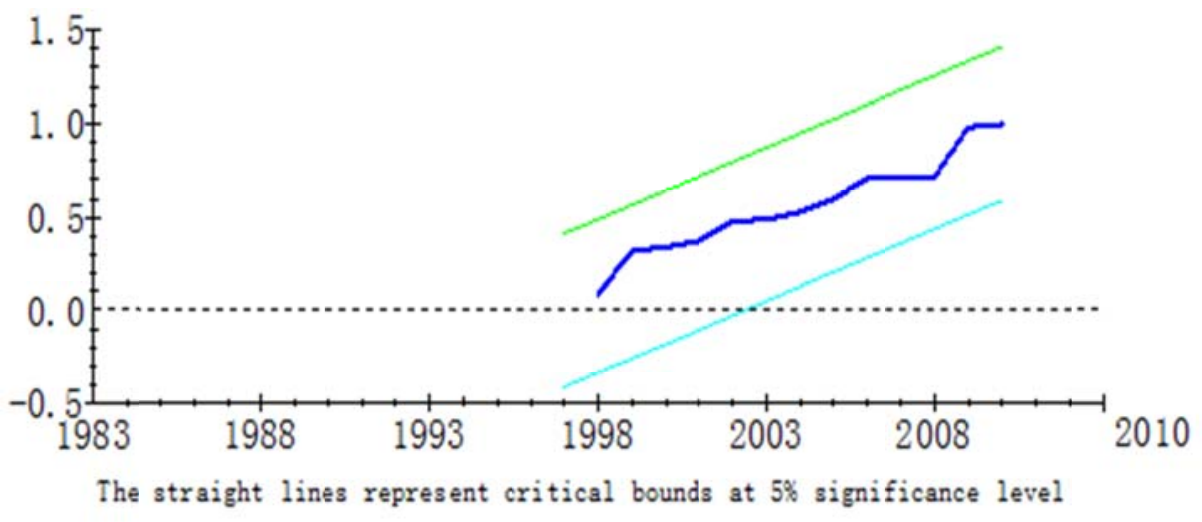

Figure 4: Cumulative sum of squares of recursive residuals

\section{B.3 CUSUM and CUSUMSQ TEST (Model C)}

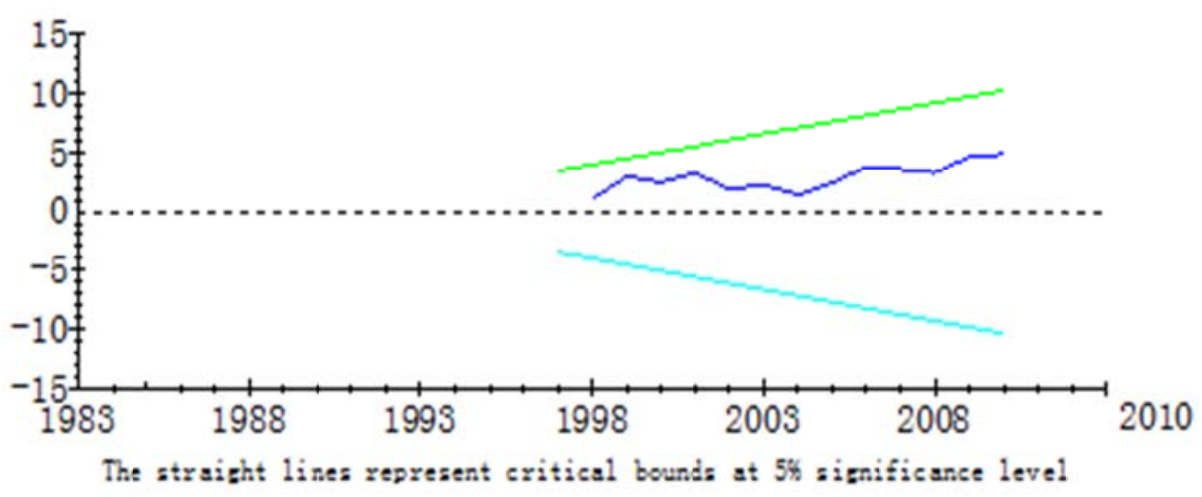

Figure 5: Cumulative sum of recursive residuals

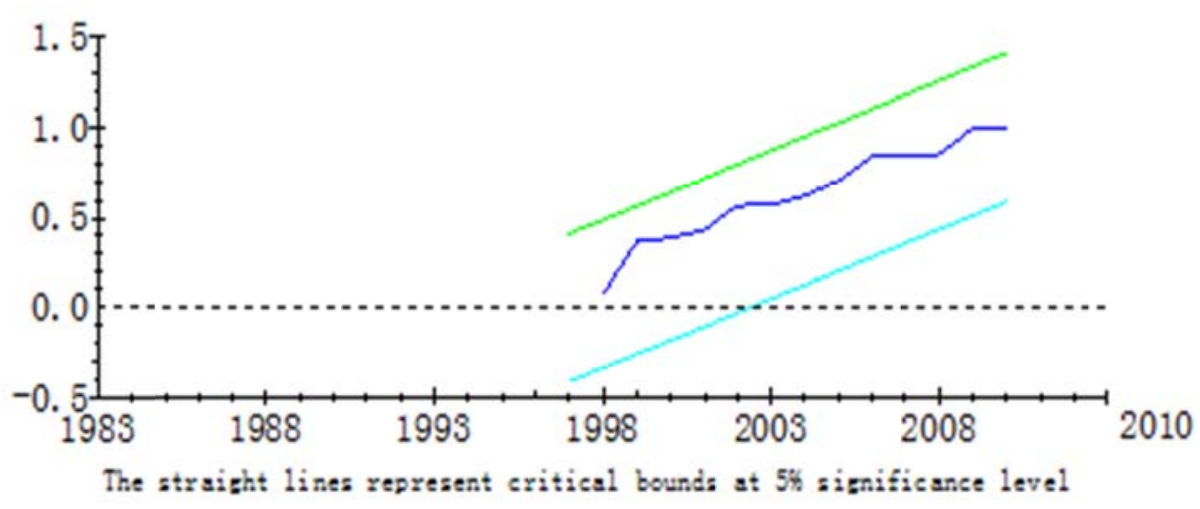

Figure 6. Cumulative sum of squares of recursive residuals 


\section{Copyright Disclaimer}

Copyright for this article is retained by the author(s), with first publication rights granted to the journal.

This is an open-access article distributed under the terms and conditions of the Creative Commons Attribution license (http://creativecommons.org/licenses/by/3.0/). 